\title{
Coulisses
}

Revue de théâtre

13 | Hiver 1996

Varia

\section{Avant les mots était le théâtre}

\section{Madeleine Velut}

\section{OpenEdition}

Journals

Édition électronique

URL : http://journals.openedition.org/coulisses/4173

DOI : $10.4000 /$ coulisses. 4173

ISSN : 2546-9460

\section{Éditeur}

Presses universitaires de Franche-Comté

\section{Édition imprimée}

Date de publication : 1 janvier 1996

Pagination : 57

ISSN : 1150-594X

\section{Référence électronique}

Madeleine Velut, «Avant les mots était le théâtre », Coulisses [En ligne], 13 | Hiver 1996, mis en ligne le 15 mars 2019, consulté le 04 octobre 2020. URL : http://journals.openedition.org/coulisses/4173 ; DOI : https://doi.org/10.4000/coulisses.4173

Ce document a été généré automatiquement le 4 octobre 2020.

Coulisses 


\title{
Avant les mots était le théâtre
}

\author{
Madeleine Velut
}

1 Pas de rideau; certains des personnages sont déjà là, derrière une grande table vide, sans doute pour une réunion, bien gras dans leur tenue de sortie bourgeoise, chemise blanche et smoking noir. A chacun son nez rouge de gros jouisseur, soit qu'il retombe telle une saucisse, ou se propulse en cap, ou s'arrondisse en pomme de terre difforme. Les retardataires accourent, s'excusent ; c'est important et pourtant, on l'apprend, c'est le lendemain du réveillon : convocation d'urgence de la part du maire.

2 Oui, l'histoire nous est contée au fil des répliques. Mais ce qui est montré nous en dit tout autant, sinon plus. Le geste révèle le caractère: le boudeur, l'indifférent, le hâbleur; les déplacements intempestifs d'un personnage, auprès du maire qui pérore le font lèche-bottes imbécile. Toute cette petite société révèle son histoire par le jeu des acteurs bien au-delà du texte. Avec leur corps, leur voix, leurs déplacements, ils tournent en dérision ce microcosme minable que l'éclosion soudaine d'une épidémie renforce dans sa fatuité, son égoïsme, sa cruauté.

Bravo pour ce travail des comédiens : une équipe au service d'une mise en scène dont le parti-pris impose un sens à ce texte, construit toute une vie entre les répliques, crée ce monde qui, hélas, n'est pas si éloigné du nôtre et donc, suscite notre réflexion au regard des phénomènes d'exclusion que subissent par exemple les personnes atteintes du Sida, les chômeurs,... autant de problèmes qui ne sont pris en considération par la classe au pouvoir que lorsqu'elle est elle-même directement concernée. 


\section{L'Epidémie}

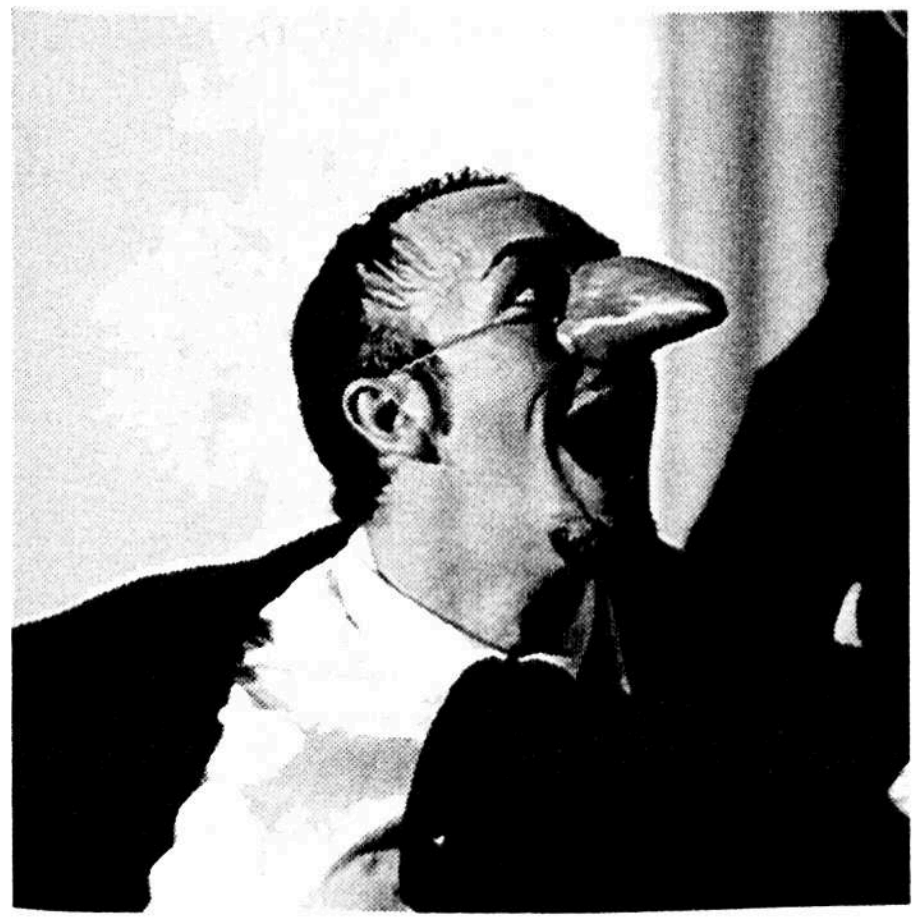

